\title{
EFFECT OF PROCESSING ON THE ENERGY VALUES OF LIMA BEAN \\ (Phaseolus lunatus)
}

\author{
A. D. OILOGHOBO an: B. L. FETUGA \\ Deparment of Animal Science, \\ University of Ibadan \\ Ibadan Nigeria.
}

(Received 27 June 1986; accepted for publication 9 March 1987).

\begin{abstract}
The energy valies of limbeans (Phaseolus lunatus) as affected by different processing treatments were determined. Average gains in body weight were $17.38 \mathrm{~g}$ for raw limabeans $48.07 \mathrm{~g}$ for cooked, $36.91 \mathrm{~g}$ for autoclaved $32.57 \mathrm{~g}$ for soaked and $31.12 \mathrm{~g}$ for germinated beans. Feed conversion efficiency was significantly improved by processing and the poorest efficiency was obtained in the raw limabeans. Digestible energy (DE) and metabolizable energy (ME) were highly positively correlated with trypsin inhibitor, tannin and hydrogen cyanide ( $\mathrm{HCN}$ ) and the variability in ME due to trypsin inhibitor was $0.29 \%(\mathrm{r}=0.13)$, while tannin accounted for $40.81 \%(\mathrm{r}=0.64)$ and $\mathrm{HCN}$ accounted for $1.51 \%(\mathrm{r}=0.58)$. ME as percentage of $\mathrm{DE}$ was the best indicator of the efficiency of energy utilization and in all raw and processed diets, high percentages of digestible energy were metabolized. It was concluded that the main problem with limabean is that relating to its digestibility and that cooking and autoclaving are the only processes that can counteract the effects of the antinutritional factors.
\end{abstract}

\section{IN'TRODUCIION}

Limabeans (Phaseolus lunatus) contain between 22 and $25 \%$ of protein and make a significant contribution to the protein and energy requirements of many Nigerians. They are grown mainly in the tropical lowlands of Cross River State, followed by the Abuja area in Niger State and Southern Benin province in Bendel State as minor arcas of production. The crop is produced in small holdings of 2 to 4 hectares per farmer with an average yield of 600 to $800 \mathrm{~kg}$ of dry seed per ha.

Their role as sources of protein is however limited by several factors including low protein digestibility (Aletor and Fetuga, 1984), flatulence (Sanche\% et $a l ; 1966)$ and the presence of numerous antinutritional constituents (OIoghobo, 1981). Although most of the antinutritional factors can generally be eliminated by adequate heat treatment, germination or soaking (Dean, 1958; Standal, 1963), conditions do prevail whereby complete destruction may not be achicveu. Soaking and germination for example, have bcen obscrved to even dccrease the biological value of legumes (Chattopadhyay and Baneriee, 1953), despite the fact that there is a slight transitory decrease in trypsin inhibit of activity.

A study (Korte, 1973) has also shown that in mixtures of ground beans and cereals prepared under field conditions in Africa, some of the antinutritional factors are not completely destroyed, and that such cooked products produce various deleterious effects.

It is important therefore to establish thosc processing treatments which are necessary to inactivate the antinutritional factors and enhance nutritive value. In the present study, the results of studies on the effect of four processes - cooking, autoclaving, soaking and germination - on antinutritional factors and energy values of three limabean varietics are reported.

Nigerian Journal of Animal Production 13(1986):86-93 


\section{MATERIALS AND METHODS}

Three varicties of limabeans were obtained from the International Institute of Tropical Agriculture, Ibadan, Nigeria and processed as follows: the raw whole beans were soaked in water overnight and germinated in sterile petri-dishes lined with wet cotton wool for $72 \mathrm{~h}$, during which sprouts of up to $2-3 \mathrm{~cm}$ in length appeared. Another batch of samples was soaked in distilled water for $72 \mathrm{~h}$ with continuous change of water, after initial washing with mercuric chloride and rinsing with distilled water. At the end of 3 days, soaked and germinated beans were rinsed in water and freeze-dried.

Cooking of the limabeans was done in pressure cookers at 15 psi for 15 minutes the cooking time being taken from the moment when pressure reached 15 psi. The cooked samples were then freezedried. The samples to be autoclaved were first milled in the raw furm and then autoclaved at $105^{\circ} \mathrm{C}$ and 10400 $\mathrm{kg} / \mathrm{sq} . \mathrm{m}$. pressure for $20 \mathrm{~min}$. The freeze-dried soaked, germinated and cooked samples were ground in a laboratory mill and along with the milled autoclaved samples, were stored at $4^{\circ} \mathrm{C}$.

\section{Chemical Analysis}

Chemical composition was determined by standard methods (AOAC, 1970). Trypsin inhibitor (TI) activity was estimated by the method of Kunitz (1964) and the end to end incubation method of Nutell (1970) was employed for the estimation of tannins. For the determination of phytic acid, a combination of the methods by Wheeler and Ferrel (1971) and Makower (1970) was used. A 4:6 $\mathrm{Fe} / \mathrm{P}$ atomic ratio was used to calculate phytic acid content. The method of Wood (1965) was used in the estimation of hydrogen cyanide.

\section{Biological trials}

Sixty four weanling male and female albino rats of the Wistar strain were used to determine energy values. The rats were divided into sixteen groups of four rats each, on the basis of weight, litter origin and sex, such that the mean group initial weights and sex ratios were identical. Each group received either the raw or processed forms of a varicty, the sixieenth group being placed on the reference diet. The composition of the reference diet is known in table 1 . The test diets were made up of the basal composition in which the test ingredient (raw or processed limabean) was incorporated at the expense of glucose monohydrate, such that 30 parts of the test material was incorporated into the reference dict. Dry feed and water were supplied ad libitum for a period of 14 days, at the end of which the rats were weighed again.

Feces and urine were collected daily in the last eight days of the experimental period and aliquot urine samples were stored in bottles containing $10 \mathrm{mI}$ $50 \%(\mathrm{~W} / \mathrm{V})$ sulphuric acid: At the end of the collection period, the bulked fecal samples for each rat were mixed and dried in a forced-air oven at $85^{\circ} \mathrm{C}$ for $48 \mathrm{~h}$.

\section{Energy Measurements}

Fecal and urinary nitrogen were determined by the micro Kjedahl method (AOAC, 1970). Their combustible energy values were determined in a Gallenkamp oxygen ballistic bomb calorimeter with thermo-chemical grade benzoic acid as a standard. From the data obtained, the digestible and metabolizable energy values of the diets were calculated on dry matter basis (Hill and Anderson, 1960) using digestible and metabolizable energy values of 3.69 and $3.61 \mathrm{kcal} / \mathrm{g}$ for glucose (Nelson et al.,1972).

\section{Statistical Analysis}

All data were subjected to factorial analysis of variance using the IBM computer SPSSH (1976 version). Linear, 


\section{OLOGHOBO and FETUGA}

TABLI: 1 .

Composition (\%) of basal diet

\begin{tabular}{|c|c|c|}
\hline Ingredients & $\%$ & \\
\hline Ghoose monohydrate & 59.00 & . \\
\hline Soybon mod (52\% protaili) & 15.00 & \\
\hline Nutubura! casein & 10.00 & \\
\hline Fistilneas (70mproten) & 5.00 & \\
\hline Browen' lied yoast & 2.50 & \\
\hline Ricollusk & 2.00 & \\
\hline Groundaut oil & 2.50 & \\
\hline Dicalcium phosplate & 1.65 & \\
\hline Zinc sulphate (anhydrous) & 0.01 & \\
\hline Manganese sulphate (anby tratus) & 0.02 & \\
\hline Calcium carbonate & 0.80 & \\
\hline Salt $(\mathrm{NaCl})$ & 0.50 & \\
\hline Vitamin mixtum* & 1.00 & \\
\hline D.L. Nethionine & 0.02 & \\
\hline
\end{tabular}

*Vitamin mixture consisted of the following: Thiamine hydrochloride $-0.06 \mathrm{mg}$; Calcium panthothenate - $1.2 \mathrm{~g} ;$ Vicotinic acil ... $4.2 \mathrm{~g}$; Inositol - $4.0 \mathrm{~g}$; para-aminobenzoic acid - 12.00g; Biotin - 0.04g; Folic acil -- 0.04g; Cyanocobalamin -0.01g; and Choline chloride $-12.00 \mathrm{~g}$.

quadratic and step-wise regression analyses were also carried out in order to establish prediction equations for the relationships between energy parameters (dependent variable $\mathrm{Y}$ ) and each individral antinutritional factor (independent variable $X$ ).

\section{RESULTS}

The performance characteristics and energy values of raw and processed limabean varieties are presented in table 3. There were highly significant $(\mathrm{P}<0.001)$ increased in weight gained by expcrimental animals fed processed limabean diets. There werc no significant varietal differences although raw Acc. 64020 produced significantly lower gains than raw Acc. 64924 and Acc. 64068 respectively.

Cooked limabean gave the hignest $(\mathrm{P}<0.01)$ feed intake while teed conversion efficiency as measured by feed intake per unit weight gain, was poorest (highest value) on the raw limabean dicts. Therc was a good positive correlation (table 5) between trypsin inhibitor (TI) and weight gain ( $\mathrm{r}=0.17)$, feed intake $(r=0.14)$ and feed conversion efficiency $(r=0.13)$. TI accounted for $2.79 \%$ of the variability in weight gain and $1.57 \%$ in feed conversion efficiency.

Digestible energy (DE) was highest $(P<0.01)$ in the cooked varieties $(3.70$ $\pm 0.10 \mathrm{kcal} / \mathrm{g})$ and lowest in the raw varicties $(2.56 \pm 10 \mathrm{kcal} / \mathrm{g})$. .Germination did not significantly increase $\mathbf{D E}$, espe- 


\section{OLOGHOBO and FETUGA}

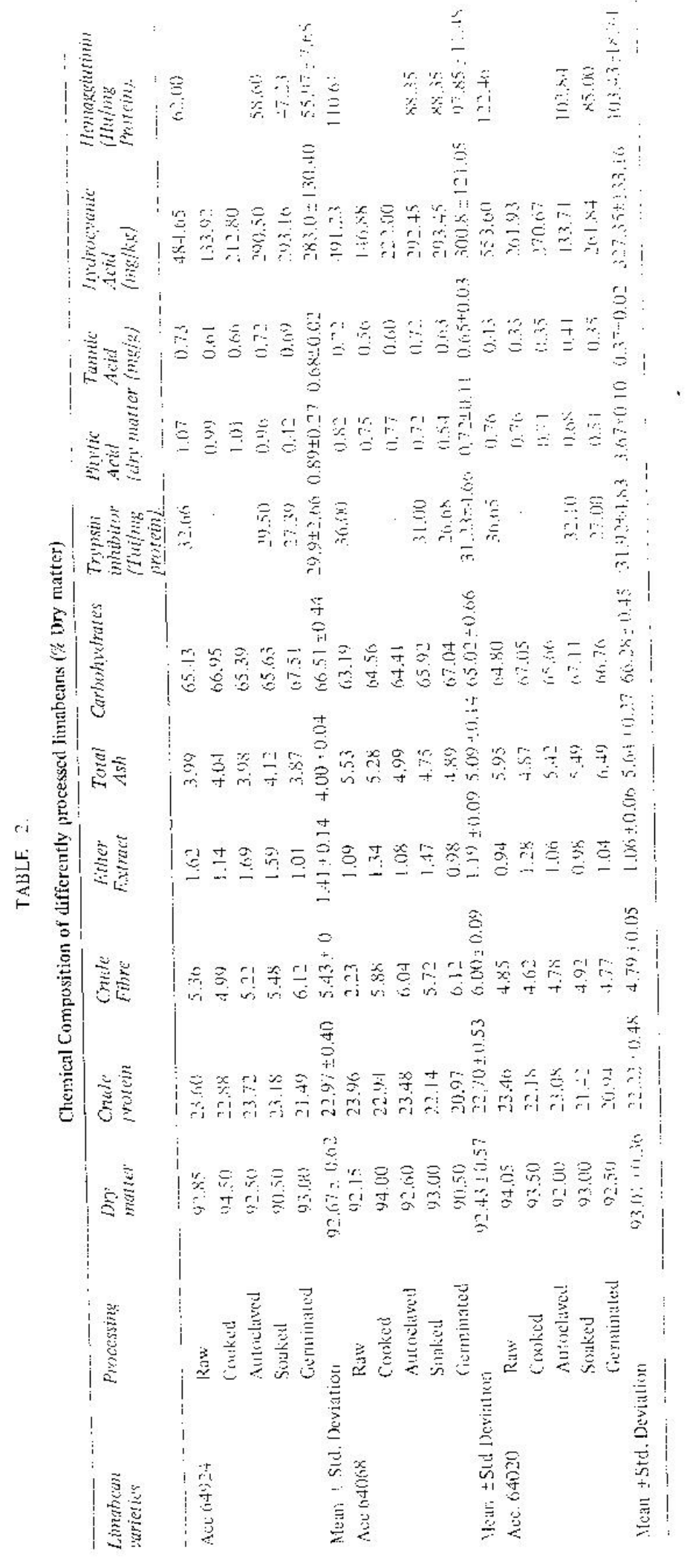




\section{OLOGHOBO and FETUGA}

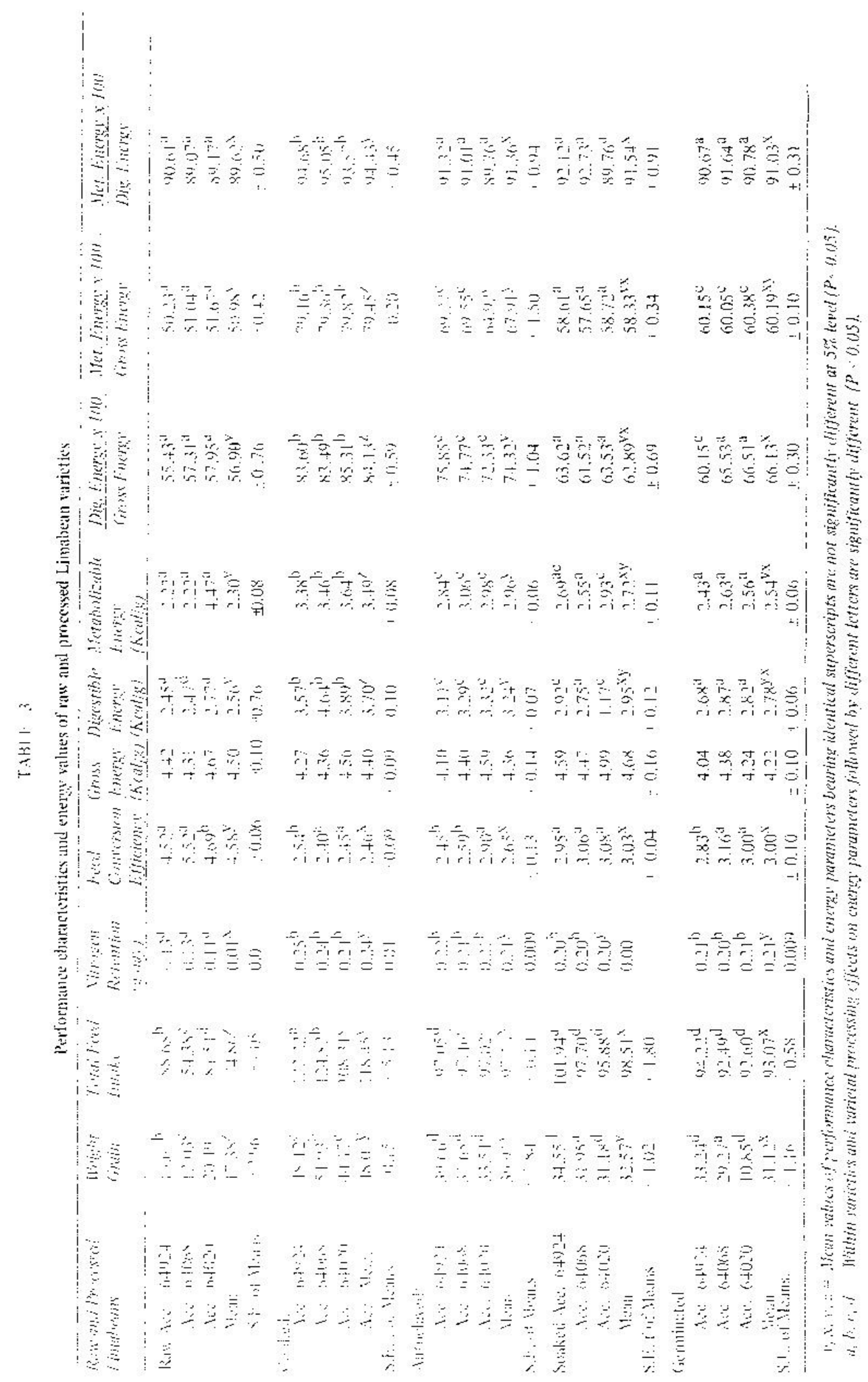


TABiBl.t. 1

Stepwise retression of antinutritional factors will pertornanec anc energy parameters

\begin{tabular}{|c|c|c|c|c|c|}
\hline $\begin{array}{l}\text { Depentent } \\
\text { Variahles }\end{array}$ & $\begin{array}{l}\text { Coefficient of } \\
\text { Determination } \\
\quad 100 \times R^{2}\end{array}$ & $\begin{array}{l}100 \times R^{2} \text { due « } \\
\text { Trypsin mhibitors } \\
\text { (Coefficient of detemmination) }\end{array}$ & $\begin{array}{l}\text { JoO } \times R^{2} \text { dite } \\
\text { is Phytic actil }\end{array}$ & $\begin{array}{l}\text { I00 } \times R^{2} \text { due }[0 \\
\text { ramic acio } \\
(C D)\end{array}$ & $\begin{array}{l}\text { I00 } \times \mathrm{R}^{2} \text { due to } \\
\text { Hydrogen cyanikie } \\
\text { (CD) }\end{array}$ \\
\hline Total Feed Intake & 14.93 & $4.75,:=0.1 .4$ & $7.20, r=0.27$ & $2.944_{i}=0.14 !$ & $0.40, r=0.03$ \\
\hline Weight gain & 3.45 & $2.79, r=0.17$ & $\therefore \quad-$ & & $0.66, \tau=0.04$ \\
\hline Feied Conversion Efficiency & 2.12 & $1.57, r=0.13$ & $0.13, \mathrm{r}=0.07$ & $0.42, I=0.05$ & - \\
\hline Xit rogen Intake & 2.04 & $0.07,1=0.01$ & $0.84, \mathrm{I}=0.09$ & $3.09 .1=0.10$ & $0.04, \tau=0.002$ \\
\hline Vitrogen Retention & 0.14 & $0.04,1=0.15$ & $0.04, r=0.21$ & $0.36, r=0.05$ & $0.05, I=0.20$ \\
\hline Nit rogen Balance & 8.07 & $1.87: \tau=0.18$ & $0.04 .5=0.19$ & $2.42, \tau=0.13$ & $0.07, r=0.01$ \\
\hline Digestible Fnergy & 3.28 & $2.87, r=0.17$ & $0.20, r=0.09$ & - & $0.21,1=0.03$ \\
\hline Metabolizable Finergy & 46.19 & $0.29, ;=0.13$ & $40.81, \mathrm{I}=0.64$ & $3.94 . r=0.02$ & $1.15, r=0.06$ \\
\hline Netaboljzable Energy & 5.01 & $0.79, \mathrm{r} \div-0.1 ?$ & - & $1.07, x=-013$ & $3.15,5=-0.18$ \\
\hline
\end{tabular}

cially in Acc. 64020 which gave a low value of $2.79 \pm 0.06 \mathrm{kcal} / \mathrm{g}$.

Simple quadratic regressions relating anti-nutritional factors and $\mathrm{DE}$ were significant $(\mathrm{P}<0.05)$ for $\mathrm{TI}$, tanmin acid and hydrogen cyanide (HCN) but not significant for phytic acid.

Metabolizable energy (ME) values ranged between 2.22 and $3.64 \mathrm{kcal} / \mathrm{g}$, being highest in cooked Acc. 64020 and lowest in raw Acc 64924 and Acc 64068 respectively. Processing very significantly $(\mathrm{P}<0.01)$ influenced $\mathrm{ME}$ and the regression of $\mathrm{ME}(\mathrm{Y})$ against all antnutritional factors gave high $R^{2}$ values and highly significant relationships for TI, tannin and hydrogen cyanide. The patterns of response were essentially curvilinear and are described by the following equations :

Trypsin inhibitor:

$$
\begin{gathered}
\mathrm{Y}=208.63-3.10 \mathrm{x}+0.52 \mathrm{x}^{2} \\
\left(\mathrm{P}<0.01 ; \mathrm{R}^{2}=0.89\right)
\end{gathered}
$$

Tannin: $\quad \mathrm{Y}=28.83-0.16 \mathrm{x}+1.01 \mathrm{x}^{2}$

$$
\left(\mathrm{P}<0.05 ; \mathrm{R}^{2}=0.43\right)
$$

Hydrogen Cyanide:

$$
\begin{gathered}
Y=203.07-0.05 x+0.80 x^{2} \\
\left(P<0.01 ; R^{2}=0.70\right) .
\end{gathered}
$$

Stepwise regression analysis combined the effects of these factors and showed that the variability in $\mathrm{ME}$ due to trypsin inbibitor intake was $0.29 \%(r=0.13)$ while tannin accounted for $40.18 \%$ $(r=0.64)$ and HCN accounted for $1.15 \%$ $(r=0.58)$.

Efficiency of energy utilization was estimated by finding $\mathrm{DE}$ as percentage of gross encrgy (GE), $\mathrm{ME}$ as percentage $\mathrm{GF}$ and $\mathrm{ME}$ as percentage $\mathrm{DE}$. Processing very significantly $(\mathrm{P}<0.01)$ : improved $\mathrm{DE}$ as $\% \mathrm{GE}$ and there was a significant $(\mathrm{P}<0.05)$ variety $\mathrm{x}$ processing interaction. Values obtained for $\mathrm{ME}$ as \% GE were highest in the cooked varieties followed by the autoclaved while raw limakeans gave the lowest values.

\section{DISCUSSION}

The inclusion of raw limabean in the diets of productive animals has been shown in many cases to reduce their performance (Aletor and Fetuga, 1984). This has been claimed to be due to the presence of various antinutritional factors particularly the protease inhibitors (Moseley \& Griffiths, 1979). Studies with these bears (Conn, 1969) have further shown that, apart from the known antinutritional factors, there is a cyanogenic glucoside which on hydrolysis yields toxic hydrocyanic acid (HCN). The cyanide ions inhibit several enzyme 


\section{OLOG:YBOBO and FETUGA}

systems, depress growth through interlerence with certain essential amino acids and utilization of associated nutrients. The present study was therefore designed to establish the processing conditions which are necessary to inactivate or eliminate the toxic antinutritional constituents of limabeans.

The reduction in weight gain for rats fed dicts containing raw limabeans compared with the processed limabean was highly significant. This reduction was partly due to a decrease in the intake of total dry matter of the raw limabeans. Significantly improved weight gains were not only obtained by feeding the processed limabean diets, but considerably much more processed feed was consumed. The significant positive correlations between trypsin inhibitor and weight gain, feed intake and feed elficiency would appar to explain that $\mathrm{TI}$ in the limabeans accounted for the reduced weight gain and poor leed tutilization. Heat treatmerit applied to the limabeans during cooking and autoclaving improved their texture and palatability, and also inactivated the neat-labile antinutritional faclors.

When feeds are consumed, the process is incvitably accompanied by heat production. The chemical make up of the raw and processed limabeans including the antinutritional contents were manifested in the degree of digestion, aborption and utilization of limabean nutrients, and gave a measure of the amount of heat that accompanied these processes. The DE and ME contents of the raw limabeans compared favourably with the values reported for cotton secd meal (Nelson et al, 1972) but are low with respect to $\mathrm{DE}$ and $\mathrm{ME}$-values of soyabean (Hill and Anderson, 1960), cowpea (Ologhobo, 1981), pigeon pea and bambara groundnut(Oyenuga, 1968). Trypsin inhibitor, tannin and hydrogen cyanide were all positively correlated with $\mathrm{DE}$ and $\mathrm{ME}$ and the significant improvement on cooking and autoclav- ing, was a consequence of the effect of these processes on the antinutritional factors. Metta and Mitchell (1954) determined the ME values of protein supplements for rats, and for soyabean, fish meal and casein, they obtained $3.45 \mathrm{kcal} / \mathrm{g}, 3.89 \mathrm{kcal} / \mathrm{g}$ and $4.80 \mathrm{kcal} / \mathrm{g}$ respectively. With the exception of casein, these values compare favourably with those obtained for cooked and autoclaved limabeans in this study. Soaking and germination had very little eflect on trypsin inhibitor and tannin contents and the ME values of the soaked and germinated limabeans for the rat were very low.

ME as percentage of DE was the best indicator of the efficiency of energy utilization since it excluded the amounts of energy lost in digestion. Results obtained show that equally high perccntages of DE were metabolized in both raw and processed limabean varieties while DE as percentage of gross energy was only fairly high in the cooked and autoclaved limabeans. Rats metabolized an average of $79.45 \%$ of $\mathrm{GE}$ in the cooked limabeans compared to $50.98 \%$, $58.33 \%$ and $60.19 \%$ utilization in the raw, soaked and germinated varieties respectively. NRC (1972) reported that in rats, $95 \%$ of the gross energy of an average purified diet is digested and that $90 \%$ is metabolized. Compared with these values, the raw, soaked and germinated limabeans were very porly digested and metabolised. Eveis a the cooked and autoclaved limabeans, the utilization of dietary energy by rats was also comparatively poor. It would thus appear that the main problems with the limabean are those relating to the digestibility of its proteins and associated nutrients. The combined effects of the antinutritional factors were paramount in these effects and although cooking and autoclaving attempted to reduce the effects of the antinutritional factors, energy values of their diets still fell short of international standards. 


\section{OLOGHOBO and FETUGA}

\section{REFERENCES}

ALETOR, $\checkmark$. A and IETUG A, B.L. (1984). Intluence of raw and cooked limabear. meals on performance, nutrient utilization and ischaridase activities in the rat.

Nutr. Rept. International 29(3). $571-578$.

A.O.A.C. (1970) Official Methods of Analysisi. 11 th ed. Washington, D.C. Association of Official Agricultural Chemists.

CHATTAPADHYAY, R. and BANERJEE, I. (1953). The nutritive value of germinated legumes in growth trials with weaning rats.

India J. Nutr. Biochem. 103: $70-$ 78.

CONN, E.E. (1969.) Cyanogenic giucoside. J. Agric. Food Chem. 17: 519-526.

DEAN, R.F.A. (1958). The use of the processed plant protein as human food. In: "Processed piant protein foodstuff" (A.M. Altschull, ed.) pp. 205-247. Academic Press New York.

HILL, F.W and ANDDERSON, D.L. (1960). Comparision of metabolizable cnergy and productive energy determi. nations with growing chick.

Poult. Sci. 39: 112. 118.

KORTE, R. (1973) Processed plant foods in high humid tropics.

Ecol. Food Nutr. 1: 303-309.

KUNITZ, M. (1964). Crystalline Soybean trypsin inhibitor 11 . General properties.

J. Gen. Physiol. 40: 291-310.

MAKOWER, R.U. (1970). Extraction and determinaton of physical acid in beans.

Cereal chemistry. 3 47:288-297,

METTA, V.C. and MITCHELL, H.H. (1954). Determination of the metabolizablo energy of organic nutrients for the rat. J. Nutr. 52: 601-612.
MOSELEY, G. and GRIFFITHS, D.W. (1979) Varietal variation in the antinutritive effects of field beans when fed to rats.

J. Sci. Food Agric. 30: 772-778.

NELSON, T.S., May, M.A. and MLLES, R.D. (1972). Digestible and metabolizable energy content of feed ingredients for rats.

J. Anim. Sci. 38: 554--558.

N.R.C. (1972) Nutrient requirements of domestic animals. No. 10 . Nutrient Requirements of Laboratory animals. Nationlat Research Council, Washington DC.

NUTELL P.M. (1970). Chemical analysis of tannin in legumes.

J. Biol. Chem. 23: 224-226

OLOGHOBO, A.D. (1981). Biochemical and Nutritional studies of cowpea and limabean with particular reference to some inherent antinutritional components. Ph.D. thesis, University of Ibadan.

OYENUGA, V.A. (1968). Nigeria's foods and feedingstuff: Their chemistry and nutritive value, Ibadan University Press Nig.

SANCHEZ, R., TAUKERM, C., MURPHY, E.L. (1966). The deveIopment of the flatulence priftciple in the maturing bean. Res. Eight dry bean Res. Conference. Bellaire, Michigan. pp. $53-58$.

STANDAL, B.R. (1963). Nutritive value of proteins of oriental soybean foods J. Nutr. $81: 279-285$

WHEELER, E.L and FERREL, R.E. (197f). A method for phytic acid determination in wheat and wheat fractions.

Cereal Chem. 48: 312-20.

WOOD, T. (1965). The cyanogenic glucoside content of cassava and cassava products.

$$
\text { J.Sci. Fd. Agric. 17: 85-90. }
$$

